\title{
Religionsforståelsen i ny rammeplan for barnehagen
}

\author{
Av Olav Hovdelien
}

I april 2017 fastsatte Kunnskapsdepartementet en ny Forskrift om rammeplan for barnehagens innhold og oppgaver. I denne artikkelen undersøkes hvilke føringer som legges til grunn for religions- og livssynsfeltet i den nye rammeplanen, og hvordan disse forholder seg til formålsbestemmelsen $i$ barnehagelovens \$1. Det argumenteres for at den nye rammeplanen bekrefter en tolkning av formålsbestemmelsen fra 2010 som innebar et brudd med tidligere formålsbestemmelsers kristne verdiforankring. Det vil si at fokuset flyttes fra kristendommen som statsreligion og hegemonisk religion på storsamfunnsnivå, til det religiøse og livssynsmessige mangfoldet som finnes på samfunnets mesonivå, og barnehagens arbeid med å bidra til å integrere dette mangfoldet under en overbygning som har menneskerettighetene som sin primare basis. Dette impliserer videre en nedtoning av kristendommens rolle som samfunnsintegrerende idétradisjon og formidling av den kristne kulturarven i barnehagen.

Nøkkelord: Barnehagens formålsbestemmelse - barnehagedidaktikk - Rammeplan for barnehagens innhold og oppgaver - kristen kulturarv - religiøst mangfold

Olav Hovdelien, f. 1968, professor, Høgskolen i Oslo og Akershus, Institutt for barnehagelcererutdanning, $\mathrm{Pb} 4$, St. Olavs plass, 0130 Oslo, Olav.Hovdelien@hioa.no

\section{INNLEDNING}

24. april 2017 ble en ny Forskrift om rammeplan for barnehagens innhold og oppgaver fastsatt av Kunnskapsdepartementet. Dette er en begivenhet for alle som er interessert i barnehagefeltet, siden det her legges føringer for i prinsippet alt som skal foregå av pedagogisk arbeid i barnehagen. Som forskrift til loven er rammeplanen en juridisk bindende fortolkning og utdypning av gjeldende barnehagelov, og som sådan underordnet denne. Det vil si at rammeplanen ikke på noen punkter skal motsi loven, men konkretisere denne og legge føringer for det konkrete daglige pedagogiske arbeidet som skal foregå i barnehagen. Endringene som skjer i og med innføringen av en ny rammeplan vil dermed prinsipielt sett ikke være store, uten at barnehageloven er blitt endret først. Det er snakk om justeringer juridisk sett. Den nye rammeplanen trådte i kraft fra 1. august 2017, og erstattet med dette forrige rammeplan for barnehagen fra 2006, og dennes oppdaterte versjon fra 2011.

Prismet - IKO-Forlaget 2017

Tilgjengelig på https://journals.uio.no/index.php/prismet. Publisert under CC BY-NC 4.0. 
En gjennomlesning av en ny rammeplan reiser mange spørsmål. I denne artikkelen skal jeg unders $\emptyset$ ke hvilke føringer som gis for barnehagens arbeid med religion og livssyn i og med den nye forskriften, med fokus på religionsforståelsen i dokumentet. I den forbindelse er barnehagens formålsbestemmelse i barnehagelovens §1 av særlig interesse som overordnet kontekst. Utgangspunktet for drøftelsen i det følgende kan dermed formuleres slik: Hva slags føringer legges til grunn om religion og livssyn på ulike samfunnsnivåer i den nye rammeplanen for barnehagen, og hvordan forholder disse føringene seg til formålsbestemmelsen i barnehagelovens $\$ 1$ ?

Forskningsmetoden som er anvendt i artikkelen består kort sagt i tolkning og drøftelse av innholdet i barnehageloven (2005) og Forskrift om rammeplan for barnehagens innhold og oppgaver (2017), med det formål å bidra til økt forståelse for innholdet i disse styringsdokumentene (jf. Gadamer 1993). Innledningsvis vil jeg presentere rammeplanen, drøfte ulike måter å tolke barnehagelovens formålsparagraf på og kort gjøre rede for begrepene religion og livssyn.

\section{NY FORSKRIFT OM RAMMEPLAN FOR BARNEHAGENS INNHOLD OG OPPGAVER (2017)}

I Norge har alle barn lovfestet rett til barnehageplass (jf. barnehageloven §12a). I barnehagen møtes barn i prinsippet på tvers av kulturell og sosial bakgrunn. Slik sett er barnehagen en viktig arena for samfunnsintegrasjon, ved at barna som deltar der, gjennomgår en kulturell sosialiseringsprosess i samhandling med hverandre og med de voksne, der hensikten er at barnehagen «skal formidle verdier og kultur, gi rom for barns egen kulturskaping og bidra til at alle barn får oppleve glede og mestring i et sosialt og kulturelt fellesskap.» (barnehageloven $\S 2$, fjerde ledd). Formidlingen av verdier og kultur skjer blant annet gjennom å lære språk, gjennom å lære hvordan de skal oppføre seg mot andre, og gjennom markering av religiøse høytider, bare for å nevne noen eksempler. Et viktig stikkord er «allsidig utvikling». Den nye rammeplanen inneholder følgende presisering i så måte: «Arbeidet med omsorg, danning, lek, læring, sosial kompetanse og kommunikasjon og språk skal ses i sammenheng og samlet bidra til barns allsidige utvikling.» (Kunnskapsdepartementet 2017:8).

Alt som nevnes i det korte sitatet ovenfor vil kunne ha relevans i forbindelse med barnas religiøse og livssynsmessige tilhørighet. Det samme gjelder når det $\mathrm{i}$ rammeplanen står at barnehagen «skal bidra til å fremme barnas tilhørighet til samfunnet, natur og kultur.» (Kunnskapsdepartementet 2017:9). Barnas tilhørighet inkluderer å fremme barnas tilhørighet også i religiøs og livssynsmessig

1 En oversikt over tidligere forskning er gitt i Hovdelien 2013; 2015. Ellers er antologien Barnehagens grunnsteiner. Formålet med barnehagen i sin helhet viet formålsbestemmelsen (Glaser m.fl. (red.) 2011). Se også Sødal 2014 og Sagberg 2012. 
forstand. Dette medfører både krav til barnehagepersonalets religions- og livssynskunnskap, og at de har de rette holdningene profesjonelt sett for å kunne utføre det pålagte samfunnsoppdraget på en tilfredsstillende måte. Ikke minst vil kravet om at personalet skal «st $\emptyset$ tte barnas refleksjoner rundt situasjoner, temaer og fenomener og skape forståelse og mening sammen med dem», stille solide krav til både innlevelse og kompetanse i møte med barnas religiøse, livssynsmessige og eksistensielle spørsmål. I forlengelse av dette er det også i tråd med den nye rammeplanens føringer at barnehagen støtter opp under barnas språk- og begrepsutvikling også på religions- og livssynsfeltet (jf. Kunnskapsdepartementet 2017:9-11).

Det norske storsamfunnet omtales ofte i dag som et flerkulturelt samfunn. Dette inkluderer et stort mangfold på religions- og livssynsfeltet. Et flerkulturelt samfunn er et samfunn der mange ulike kulturelle, religiøse og livssynsmessige grupper til dels lever ved siden av hverandre, og til dels er innvevd i hverandre. Samtidig vil samfunnsgruppene ideelt sett være en integrert del av det norske storsamfunnet med den respekten for dets fellesinstitusjoner, lovverk, språk osv. som trengs i så måte (jf. Parekh 2006). Barnehagen er en samfunnsinstitusjon som er tiltenkt en slik oppgave (Hovdelien 2015:307-309). Barnehageloven og rammeplanen er normative dokumenter, som gjenspeiler dette, i den forstand at de uttrykker en retning og gir rammer for den kulturelle påvirkningen som skal skje i barnehagen: «Barnehagen skal være en pedagogisk virksomhet som skal planlegges og vurderes. Barn og foreldre har rett til medvirkning $\mathrm{i}$ disse prosessene.» (Kunnskapsdepartementet 2017:13). Barns og foreldres rett til medvirkning gjelder naturlig nok også på religions- og livssynsfeltet.

\section{BARNEHAGENS FORMÅLSBESTEMMELSE}

Barnehagens formålsbestemmelse er i dag uttrykt slik i barnehagelovens $\$ 1$, første ledd, under overskriften 'Formål':

Barnehagen skal i samarbeid og forståelse med hjemmet ivareta barnas behov for omsorg og lek, og fremme laering og danning som grunnlag for allsidig utvikling. Barnehagen skal bygge på grunnleggende verdier $i$ kristen og humanistisk arv og tradisjon, slik som respekt for menneskeverdet og naturen, på åndsfrihet, nestekjærlighet, tilgivelse, likeverd og solidaritet, verdier som kommer til uttrykk i ulike religioner og livssyn og som er forankret i menneskerettighetene.

I likhet med andre lovformuleringer kan også barnehagens formålsbestemmelse forstås og fortolkes på ulike måter. Her er det særlig to ulike tolkninger av loven som synes aktuelle. Den første tolkningen, som vi kan kalle kontinuitetstolkningen, tar utgangspunkt i rekkefølgen av de ulike leddene i formålsbestemmelsen, og 
argumenterer for at rekkefølgen i leddene innebærer at «grunnleggende verdier i kristen og humanistisk arv og tradisjon» har forrang fremfor andre verdiuttrykk. Slik betones kontinuiteten tilbake til den tidligere formålsbestemmelsen i barnehageloven av 1983, og vektleggingen av en kristen verdiforankring, som ble videreført i 1995 (jf. Hagesæther 2011:29-30). Den gamle formålsbestemmelsen hadde følgende ordlyd i barnehagelovens §1: «Barnehagen skal hjelpe til med å gi barna en oppdragelse i samsvar med kristne grunnverdier.» I og med denne formålsbestemmelsen hadde barnehagen en tydelig uttrykt idémessig forankring i kristendommen. Denne var begrunnet ut fra at godt over $90 \%$ av befolkningen i og med sitt medlemskap i statskirken eller et annet kristent trossamfunn gav uttrykk for at de ønsket at barna deres skulle få en kristen oppdragelse, i det minste i kulturell forstand. «Kristne grunnverdier» var forbundet med statskirken og dennes idégrunnlag og praksiser. Slik sett var den gamle barnehagelovens §1 et uttrykk for religion på storsamfunnsnivå.

De som står for en kontinuitetstolkning, vil kunne henvise til formålsbestemmelsens forarbeid i Bostadutvalget (NOU 2007:6), og hvordan utvalgets forslag ble endret på veien til Stortinget. Bostadutvalgets forslag hadde følgende ordlyd under overskriften «Utvalgets forslag»:

Barnehagen skal i samarbeid og forståelse med hjemmet ivareta barnas behov for omsorg og lek, og fremme laring og danning som grunnlag for allsidig utvikling. Barnehagen skal bygge på respekt for menneskeverdet, på åndsfrihet, nestekjœrlighet, likeverd og solidaritet, slik disse grunnleggende verdiene kommer til uttrykk $i$ kristen og humanistisk tradisjon, $i$ ulike religioner og livssyn, og slik de er forankret i menneskerettighetene. (NOU 2007:6, s.13).

Vi ser her at «kristne og humanistiske verdier» nevnes først etter at en rekke antatte fellesverdier uavhengig av religion og kultur er ramset opp. Hvis vi leser innstillingen til Odelstinget, ser vi derimot at Bostadutvalgets forslag er blitt endret til det som ble vedtatt og er gjeldende lovformulering (Innst. O. nr. 18 (2008-2009): 2-4). Hvis ikke rekkefølgen hadde betydning, hvorfor ble den da endret fra Bostadutvalgets innstilling til den formålsbestemmelsen som ble vedtatt av Stortinget? Endringen skyldes at det ble gjort et tverrpolitisk forlik, der de som mente at en slik språklig omrokkering ville innebære at barnehagens kristne og humanistiske verdiforankring ble fremhevet, vant frem.

Etter min mening er det en feilslutning å legge så stor mening ned i rekkefølgen av de ulike leddene i Bostadutvalgets forslag til formålsparagraf. Rekkefølgen kan nok ha hatt en viss symbolsk verdi for å få støtte fra partier på Stortinget, men uten at det egentlig er snakk om reelle forskjeller når det gjelder hva formuleringen språklig sett uttrykker. Uansett, feilslutning eller ikke, en slik tolkning innebærer at kontinuiteten i forhold til barnehagens gamle utgave av 
formålsbestemmelsen vektlegges, og at rekkefølgen i leddene i den nye utgaven av paragrafen anses som vesentlig i forhold til meningsinnholdet (jf. Sagberg 2011:95-98; Hovdelien 2012:10-12; NOU 2007:6; Ot.prp. nr. 47 (2007-2008); Innst. O. nr. 18 (2008-2009); Besl. O. nr. 43 (2008-2009)).

De som står for en alternativ tolkning, som vi kan kalle bruddtolkningen, vil argumentere for at formålsbestemmelsen fra 2010 innebar et brudd med barnehagens tidligere kristne formålsparagraf. Formålsparagrafens innhold leses som en liste over verdier som er forankret i sideordnede religions- og livssynstradisjoner (inkludert menneskerettighetene). Altså: Først slås det fast at «Barnehagen skal bygge på grunnleggende verdier i kristen og humanistisk arv og tradisjon», deretter følger det en rekke eksempler på hva kristen og humanistisk arv og tradisjon innebærer: «... slik som respekt for menneskeverdet og naturen, på åndsfrihet, nestekjærlighet, tilgivelse, likeverd og solidaritet», før det slås fast at det samtidig er snakk om «verdier som kommer til uttrykk i ulike religioner og livssyn», før formålsbestemmelsen oppsummerer med at det alltid er snakk om verdier «... som er forankret i menneskerettighetene.» En slik tolkning innebærer at menneskerettighetene forstås som uttrykk for et verdimessig minste felles multiplum, og vil i praksis bli forstått som overordnet de andre religions- og livssynstradisjonene (jf. Sødal 2009:19; Hovdelien 2012:1012).

Jeg støtter bruddtolkningen av lovbestemmelsen i \$1, første ledd. En slik tolkning finner også støtte i følgende avsnitt fra den nye rammeplanen:

Uavhengig av om barnehagen velger en annen innfallsvinkel til formålsbestemmelsen eller fastsetter scerlige bestemmelser om livssynsformål, er barnehagen forpliktet til å ivareta verdiene i formålsbestemmelsen som er forankret i menneskerettighetene. Alle barnehager, uansett eierforhold, er forpliktet til å drive barnehagen i samsvar med dette felles verdigrunnlaget; respekt for menneskeverdet og naturen, åndsfrihet, nestekjerlighet, tilgivelse, likeverd og solidaritet. (Kunnskapsdepartementet 2017:7).

En viktig kontekst for det siterte avsnittet fra rammeplanen er ellers følgeendringene som ble gjort i forbindelse med innføringen av ny formålsbestemmelse fra og med 1. august 2010. Formålsparagrafens ordlyd var blitt vedtatt allerede i desember 2008, men trådte ikke i kraft før i august 2010, på grunn av at følgeendringene ikke ble avklart før i juni samme år. Disse følgeendringene gikk i korte trekk ut på at private barnehager fortsatt kan velge bort verdiforankringen i kristen og humanistisk arv og tradisjon. Det ble samtidig presisert at eiere av private barnehager og barnehager som eies eller drives av menigheter i Den norske kirke, også fortsatt vil kunne vedtektsfeste særlige bestemmelser om livssynsformål som et tillegg til formålsbestemmelsen (jf. Barnehageloven §1a). I det siterte avsnittet fra den nye rammeplanen presiseres det også at barneha- 
gens verdiformidling skal foregå innenfor rammen av menneskerettighetene, og at også private barnehager «er forpliktet til å ivareta verdiene som er forankret i menneskerettighetene.»

Før vi kan gå nærmere inn på hva dette har å si for håndteringen av religion og livssyn i det pedagogiske arbeidet $\mathrm{i}$ barnehagen, er det nødvendig å se på hvordan religion og livssyn opptrer på tre ulike samfunnsnivåer, etter en kort gjennomgang av begrepene 'religion' og 'livssyn'.

\section{Begrepene 'Religion' OG 'LivSSyn'}

Den amerikanske religionssosiologen Peter Berger definerer religion som «oprettelsen af et helligt kosmos» i sin innflytelsesrike bok fra 1967 (Berger 1997:157). ${ }^{2}$ Berger presiserer i den forbindelse at han bruker den helt avgjørende kategorien 'det hellige' på samme måte som den er blitt teoretisk utviklet og forankret av den tyske religionshistorikeren Rudolf Otto. Ved å knytte an til Ottos kategori om 'det hellige', knytter Berger samtidig an til ulike religioners oppfattelse av dette, slik det foreligger empirisk som en del av de troendes forestillingsverden. Pål Repstad følger opp med å bestemme innholdet i religionsbegrepet som «livstolkninger og praksis som regner med en virkelighet som går ut over det dennesidige, hverdagslige, rasjonelle - ut over det som vi kan gripe og forstå med fornuft og sanser.» (Repstad 2000:24). I sin diskusjon av begrepet 'livssyn', og avklaringen opp mot religionsbegrepet, beskriver idéhistorikeren Per Magne Aadnanes 'livssyn' som en kognitiv størrelse. Innholdsmessig kan begrepet 'livssyn' sies å omfatte følgende tre hovedområder, ifølge ham: (1) Virkelighetsoppfatning, det vil si en oppfatning av hva som er virkelig, om det finnes en gud osv., (2) Menneskesyn, en oppfatning av hva slags vesen mennesket er, om det har et liv etter døden, om menneskelivet har en gitt mening osv., og (3) Verdi- og moraloppfatning, en oppfatning av hva som er godt, rett og skjønt (Aadnanes 2012:22). Ut fra en slik definisjon av begrepet 'livssyn' vil alle mennesker ha et livssyn, mer eller mindre konsistent eller sammenhengende, og mer eller mindre reflektert og artikulert. Samtidig vil også livssyn være et kollektivt begrep som refererer til en livssynstradisjon, som ofte i norsk sammenheng igjen vil være knyttet til en institusjon.

\section{RELIGION OG LIVSSYN P̊̊ TRE SAMFUNNSNIVÅER}

En enkel samfunnsmodell vil være å peke på at samfunnet består av tre nivåer, henholdsvis storsamfunnsnivået, individnivået og mesonivået (jf. Østerberg og Engelstad 1995:19-20). Et samfunn eller storsamfunn som sosiologisk begrep betegner en ordning mellom mennesker som er så omfattende at den om

2 Standard innføringsbøker for en samfunnsfaglig tilnærming til religion er Inger Furseth og Pål Repstad Innføring i religionssosiologi (Oslo: Universitetsforlaget 2003) og Pål Ketil Botvar og Ulla Schmidt (red.) Religion $i$ dagens Norge. Mellom sekularisering og sakralisering (Oslo: Universitetsforlaget 2010). 
nødvendig kan være selvproduserende og selvrekrutterende (Østerberg 2003:141). Dermed har vi fått fastlagt det øverste analytiske samfunnsnivået $\mathrm{i}$ samfunnsmodellen, storsamfunnsnivået. Dette vil i mange tilfeller kunne knyttes til nasjonalstaten. Det er videre et kjennetegn ved nasjonalstaten at den omfatter et kulturelt rammeverk som er kjent for innbyggerne, og som kanskje tydeligst kommer til uttrykk i lovverket og håndhevelsen av dette. Hvis vi begynner i den andre enden, kan vi raskt slå fast at det nederste samfunnsnivået som vil være aktuelt å analysere ut fra, består av samfunnets enkeltindivider. Dette nivåt kan dermed betegnes som individnivået. Det norske storsamfunnet utgjør en omfattende helhet av sosiale relasjoner og strukturer, basert på at den store mengden individer til dels samles om det som kan betegnes som den norske kulturen, dels har ulik kulturell tilhørighet basert på blant annet etnisk og religiøs tilknytning. For å få fanget opp det norske samfunnets flerkulturalitet og flerreligiøsitet, er det nødvendig å innføre et tredje nivå som jeg har valgt å knytte til betegnelsen mesonivået. Mangfoldet av ulike grupperinger på mesonivået er stort og uoversiktlig, og alle fors $\emptyset \mathrm{k}$ på å ordne dette mangfoldet blir ufullstendige og foreløpige. Samtidig er det nødvendig å operere med et slikt mesonivå for à synliggjøre at det norske storsamfunnets flerreligiøsitet og flerkulturalitet ikke fremkommer tydelig hvis vi bare snakker om to nivåer (jf. Hovdelien 2011:31).

\section{Kristen kulturarv - historisk begrunnelse for kristendommens særstilling}

Det er særlig to grunner til at kristendommen har vært vektlagt sterkere enn andre religioner og livssyn i norske barnehager. For det første har kristendommen vært den viktigste religionen i Norge i om lag tusen år, og dernest har det store flertallet nordmenn vært medlemmer av et kristent trossamfunn, med Den norske kirke som dominerende institusjon i kraft av å ha vært statskirke. Over tusen år med kristen påvirkning har naturlig nok satt sine spor både på den norske kulturen og det norske samfunnet (jf. Repstad 2016: 255-260). Når det er snakk om kristen kulturarv, handler dette om at Norge har en tusenårig kristen tradisjon, der kristendommen har vært en avgjørende kulturinpuls som har medført at det mange ganger er vanskelig å skille mellom det som er kristent og det som er norsk. I barnehageloven er kristendommen knyttet sammen med humanismen som åndstradisjon, konkretisert ved menneskerettighetene. Dette er ikke tilfeldig. Når de store åndstradisjonene står slik sammen, er grunntanken bak at disse ikke skal skilles. Historisk sett vokste da også humanismen frem i en kristen kultur. På tilsvarende måte er det vanskelig å si hva som er kristen kulturarv og hva som er norsk kulturarv. De verdiene og normene som det norske samfunnet tradisjonelt har vært tuftet på, har vært verdier som vi finner igjen i kristendommen, og slik er det langt på vei fortsatt. Et eksempel på dette er 
høytidstradisjonene. Både jul, påske, pinse og Kristi himmelfartsdag står trygt på kalenderen, selv om nordmenn flest går sjelden i kirken. Den kristne kulturarven viser seg også i og med den store interessen for å inngå ekteskap i kirken, få barna døpt og konfirmert, samt ved gravferd. Kulturarven er også viktig for et lands identitet. Tidsregningen vi bruker i Norge, begynner ved Kristi fødsel. Det norske flagget inneholder et kristent kors. Nasjonalsangen inneholder flere eksplisitte henvisninger til kristendommen osv. Listen kan forlenges.

\section{Statskirkekristendom - institusjonalisert religion på storsamfunnsnivå}

Et konkret eksempel på religion på storsamfunnsnivå i Vesten har vært ordningen med statskirker. Som statskirke utgjorde Den norske kirke det helt dominerende tros- og livssynssamfunnet på norsk mark, helt fra reformasjonstiden på 1500-tallet og frem til et visst tros- og livssynsmangfold vokste frem fra 1800-tallet og fremover. Men det er først i løpet av de siste tiårene at Den norske kirke ikke lenger har over $90 \%$ av befolkningen blant sine medlemmer. Så sent som i 1960 var for eksempel andelen statskirkemedlemmer $96 \%$ (Repstad 1984:71). Det er ellers verdt å merke seg at når oppslutningen til Den norske kirke i 2017 har sunket til 71,5\% av befolkningen, henger dette ikke først og fremst sammen med at mange har meldt seg ut av kirken (SSB 2017a). Dette henger sammen med $\emptyset$ kende innvandring. I 2015 var andelen innvandrere og norskfødte med innvandrerbakgrunn på 16,8 \% (SSB 2017b). De færreste av disse har meldt seg inn i Den norske kirke. Hvis vi tar høyde for dette, fremkommer det at det har vært mye mindre nedgang $i$ andelen etnisk norske medlemmer av Den norske kirke enn det ved første øyekast kan se ut til.

På den annen side vil det, med tanke på den økende innvandrerandelen $\mathrm{i}$ befolkningen, uansett bli gradvis mer problematisk å forstå Den norske kirke som en samfunnsinstitusjon som hører hjemme på storsamfunnsnivå, mens alle andre kirker og trossamfunn tilhører mesonivået i samfunnet. Barnehagens kristne formålsparagraf fra 1983 var et eksempel på en formålsparagraf som favoriserte en bestemt religion, nemlig kristendommen, underforstått luthersk statskirkekristendom. Barnehagen skulle hjelpe til med å gi barna en oppdragelse i samsvar med kristne grunnverdier. Med små endringer var det denne formålsparagrafen som fikk avløsning med den nye formålsparagrafen som ble gjort gjeldende fra og med høsten 2010.

\section{Sheilaisme - religion og livssyn på samfunnets individnivå}

Hvis vi begynner i den andre enden enn storsamfunnsnivået, kan vi raskt slå fast at det nederste samfunnsnivået som vil være aktuelt å analysere samfunnet ut fra, består av samfunnets enkeltindivider. Dette nivået kan dermed betegnes 
som individnivået. Det norske storsamfunnet utgjør en omfattende helhet av sosiale relasjoner og strukturer, basert på at den store mengden individer til dels samles om det som litt løst kan betegnes som den norske kulturen, dels har ulik kulturell tilhørighet basert på blant annet etnisk og religiøs tilknytning. Religion på individnivå kan få sitt utslag i ekstrem religiøs individualisme. Den religionssosiologiske termen for slik ekstrem religiøs individualisme er sheilaisme, etter et begrep som den amerikanske religionsforskeren Robert Bellah med flere introduserte i boken Habits of the Heart (Bellah et al. 1996), Bellah beskriver denne formen for religiøs individualisme slik:

I forbindelse med arbeidet med Habits of the Heart, intervjuet vi en ung kvinne som hadde kalt opp sin egen religion etter seg selv. Sheila Larson er en ung sykepleier som har gått mye i terapi og beskriver sin tro som 'sheilaisme'. Dette åpner opp for muligheten av at det er mer enn 235 millioner amerikanske religioner, en for hver av oss. «Jeg tror på Gud», sier Sheila, "Jeg er ikke en religiøs fanatiker. Jeg kan ikke huske forrige gang jeg var i kirken. Min tro har hjulpet meg lenge. Det er «sheilaisme». Bare min egen lille stemme. (sitert fra Bellah 1986, min overs.)

Ved å definere det hun kaller sin egen «sheilaisme», gir Bellahs informant uttrykk for en rendyrket individualisme, men det er en individualisme med gode hensikter. Hun fortsetter slik, ifølge Bellah: "Jeg tror Gud vil at vi skal ta vare på hverandre.» En slik privatreligiøs individualisme bryter tilsynelatende med forestillingen om at religion som kulturelt fenomen er samfunnsbestemt. Men for å si med Østerberg og Engelstad (1995: 381): «At hver enkelt samfunnsdeltaker skulle ha sin egen religion, er omtrent like sannsynlig eller like usannsynlig som at hvert menneske skulle ha sitt eget språk.» Individualiseringen har sine grenser. Religionsut $\emptyset$ velse skjer i samhandling med andre mennesker. Det er samtidig viktig å minne om at mye religiøst liv har en forholdsvis svak tilknytning til religiøse institusjoner som kirker, bedehus eller moskeer.

Tendensen i retning av $\emptyset \mathrm{kt}$ religiøs privatisering henger sammen med gjennombruddet av det moderne, samtidig som mye av den privatiserte religiøsiteten har med seg forestillinger og praksiser som den har hentet fra organisert institusjonell religion. Ifølge Repstad er det i tillegg en tendens til at religionen blir mer deregulert, i betydningen at folk ikke nødvendigvis tror mindre enn tidligere, men det man tror, er mindre kirkestyrt enn før (Repstad 2000: 35). Litt tabloid kan vi kanskje kalle dette en 'koldtbordisering' av religion, der den religiøse velger ut en del av trosinnholdet i en religion og fastholder dette, eventuelt blander med religiøse forestillinger hentet fra andre steder. Det er altså en tendens til at mange folk er religiøse, men på sin egen personlige måte. Forestillingen om at man kan være en god kristen uten å gå i kirken eller på religiøse møter, kan forklares på grunn av dette. 
Det kan være interessant innen religionsforskningen å fokusere på religiøs og livssynsmessig individualisering, men i barnehagesammenheng er ikke dette særlig interessant. Det vil si utover å vise til at både barnehageloven og rammeplanen er opptatt av å ta hensyn til alle barns individuelle behov og alle foreldres individuelle $\emptyset$ nsker (jf. Kunnskapsdepartementet 2017:4). Når det er sagt, er det ikke slik at religiøs og livssynsmessig tradisjonsformidling, for eksempel i forbindelse med høytidsmarkeringer, gir mening som uttrykk for individuelle ønsker. Når det er snakk om verdi og kulturformidling, inkludert religion, gir dette bare mening som uttrykk for fellesskap og kultur. Hvis Sheila i eksemplet ovenfor hadde hatt barn i norsk barnehage, kunne hun ikke uten videre kreve at hennes helt personlige livssyn skulle få stor plass i barnehagen. I noen tilfeller er det slik at barnehagen for eksempel markerer en religiøs høytid som bare ett enkelt barn i barnegruppen har et forhold til. Men da gjøres dette for å markere det religiøse fellesskapet som barnet og foreldrene har en tilhørighet til. Religion og livssyn er kollektive størrelser. Dette gjelder naturligvis selv om det vil være svært ulik grad av religiøst og livssynsmessig engasjement blant foreldrene, noe som for $\emptyset$ vrig alltid stiller store krav til foreldresamarbeidet.

\section{Diversitet på gruppenivå - Religion og livssyn på samfunnets mesonivå}

Alle religiøse organisasjoner som vi har i Norge vil kunne regnes til samfunnets mesonivå, enten det er snakk om religiøse organisasjoner med tilknytning til Den norske kirke, frikirkeligheten, eller religiøse organisasjoner og grupper tilh $\emptyset$ rende andre religioner enn kristendommen. I barnehageloven § 2 «Barnehagens innhold », tredje og fjerde ledd, står følgende:

Barnehagen skal ta hensyn til barnas alder, funksjonsnivå, kjønn, sosiale, etniske og

kulturelle bakgrunn, herunder samiske barns språk og kultur.

Barnehagen skal formidle verdier og kultur, gi rom for barns egen kulturskaping og bidra til at alle barn får oppleve glede og mestring i et sosialt og kulturelt fellesskap.

Her gis det eksplisitte føringer for at barnehagen skal ta hensyn til barnas etniske og kulturelle, inkludert religiøs bakgrunn, en formulering som kan synes unødvendig gjentagende, siden etnisitet nettopp handler om kulturelt fellesskap (jf. Hylland Eriksen og Sørheim 2006:52-54). Videre presiseres det at barnehagen skal «motarbeide alle former for diskriminering», og motarbeidelse av diskriminering på kulturelt grunnlag må antas å utgjøre en viktig del av dette. Den sentrale begrunnelsen for å endre formålsbestemmelsene for barnehagen i 2010, var utviklingen i retning av et mer sekularisert, men samtidig kulturelt mangfoldig samfunn (jf. NOU 2007, 6; Innst.O.nr. 18 (2008-2009)). Barnehagen må forholde seg til religion på mesonivå, i form av både de «nye» religio- 
nene som har fått fotfeste i Norge særlig i løpet av de siste 30-40 årene, som islam, buddhisme, hinduisme osv., men også det interne kristne mangfoldet, representert ved ulike mer eller mindre organiserte retninger og tilnærminger til kristen tro, vil høre hjemme her. Når barnehagen i henhold til formålsbestemmelsen skal bygge på «verdier som kommer til uttrykk i ulike religioner og livssyn», eller skal «synliggjøre variasjoner i verdier, religion og livssyn» (Kunnskapsdepartementet 2017:4-5), for å ta to eksempler, er det snakk om religion på samfunnets mesonivå.

\section{RELIGION OG LIVSSYN BARE PÅ SAMFUNNETS MESO-NIVÅ?}

Når formålsbestemmelsen fra og med 1. august 2010 ble erstattet av den mer omstendelige formuleringen vi så nærmere på ovenfor, innebar det dermed, gitt den tolkningen av formålsbestemmelsen jeg har gitt min tilslutning til, at kristendommen ikke lenger regnes som et relevant uttrykk for religion på storsamfunnsnivå. Ut fra en tolkning som innebærer at ulike religions- og livssynstradisjoner sidestilles som leverandører av verdier, så lenge disse er $\mathrm{i}$ samsvar med menneskerettighetene, vil nødvendigvis den idémessige forankringen i kristen tro og kulturarv bli nedtonet. Slik blir kristendommen «flyttet ned» til mesonivået, på linje med andre religioner og livssyn (jf. Besl.o. nr. 43 (2008-2009). Innst. O. nr. 18 (2008-2009)).

Og videre, når det i den nye rammeplanen presiseres at fagområdet etikk, religion og filosofi «retter særlig oppmerksomhet mot barnehagens samfunnsmandat og verdigrunnlag $i$ et samfunn preget av livssynsmangfold.», forsterkes tolkningen av at religion og livssyn er fenomener som hører hjemme på samfunnets mesonivå (Kunnskapsdepartementet 2017: 21). Følgende sitat fra rammeplanen er talende i så måte:

Barnehagen skal la barna få kjennskap til fortellinger, tradisjoner, verdier og høytider $i$ ulike religioner og livssyn og erfaringer med at kulturelle uttrykk har egenverdi. Barnehagen skal skape interesse for samfunnets mangfold og forståelse for andre menneskers livsverden og levesett. (Kunnskapsdepartementet 2017: 21).

Sitatet knytter her religion og livssyn til «andre menneskers livsverden og levesett», der «andre» kan leses som «andre enn majoriteten og representantene for storsamfunnets flertallskultur». En slik tolkning av sitatet peker også i retning av at religion og livssyn er noe som hører til på mesonivået. En forutsetning for denne tolkningen ligger $i$ at formuleringen «andre menneskers livsverden og levesett» leses i lys av setningen foran, der det henvises til at barna skal «få kjennskap til fortellinger, tradisjoner, verdier og høytider i ulike religioner og livssyn ...» Formuleringen «samfunnets mangfold» er også 
nærliggende å forstå som at det handler om det mangfoldet som finnes på mesonivået i samfunnet, samfunnsgruppenivået, enten det er snakk om kulturelt eller religiøst mangfold.

Riktignok presiseres det lenger ned på siden at barnehagen gjennom fagområdet etikk, religion og filosofi skal «bidra til at barna får kjennskap til grunnleggende verdier i kristen og humanistisk arv og tradisjon», men også her står denne formuleringen sammen med «og blir kjent med religioner og livssyn som er representert i barnehagen.» (Kunnskapsdepartementet 2017:21). Tilsvarende gjelder for kulepunktet der det står at «Personalet skal gi barna kjennskap til og markere merkedager, høytider og tradisjoner i den kristne kulturarven og andre religioner og livssyn som er representert $i$ barnehagen.» (Kunnskapsdepartementet 2017:22). Det at religion og livssyn også har relevans på storsamfunnsnivå, synes dermed å være lite aktuelt hos de som har utarbeidet den nye rammeplanen. Dette gjelder naturlig nok også for barnehagens formålsbestemmelse, hvis den tolkningen som vi har argumentert for ovenfor, legges til grunn. Dette er det da også liten grunn til å bli overrasket over, siden loven er overordnet forskriften i juridisk forstand, og at disse styringsdokumentene ikke skal motsi hverandre. Her foreligger det ingen diskrepans mellom loven og forskriften.

\section{Avsluttende sideblikk - Forholdet til Grunnlovens \$2}

Forskrift om rammeplan for barnehagens innhold og oppgaver (2017) gjenspeiler den samme utviklingen som førte til at grunnlovens paragraf 2 ble vedtatt endret av Stortinget 21. mai 2012 (jf. https://lovdata.no/dokument/NL/lov/1814-05-17 ). Det som skjedde denne dagen, var for det første at \$ 2, som siden religionsfriheten ble tatt inn i loven i 1964 hadde hatt følgende formulering: «Alle indvaanere av Riget have fri religions $\emptyset$ velse. Den evangelisk-lutherske Religion forbliver Statens offentlige Religion. De Indvaanere, der bekjende seg til den, ere forpliktede til at oppdrage sine Børn i samme.», nå ble endret til: «Verdigrunnlaget forblir vår kristne og humanistiske arv. Denne Grunnlov skal sikre demokratiet, rettsstaten og menneskerettighetene.» Dernest ble det vedtatt en endring av paragraf 16, for å avvikle Kongens kirkestyre og garantere at Den norske kirke forblir en folkekirke, samtidig som kirken fortsatt sikres finansiering fra den norske stat. Paragraf 16 i grunnloven lyder nå slik:

Alle innbyggere i riket har fri religionsutøvelse. Den norske kirke, en evangelisk-luthersk kirke, forblir Norges folkekirke og understøttes som sådan av staten. Ncermere bestemmelser om Kirkens ordning fastsettes ved Lov. Alle tros- og livssynssamfunn skal understøttes på lik linje. 
Fra og med 21. mai 2012 er dermed det kristne hegemoniet på storsamfunnsnivå formelt brutt, selv om staten fortsatt pålegges å underst $\emptyset$ tte Den norske kirke, på lik linje med andre tros- og livssynssamfunn. Samtidig er det fortsatt slik at grunnloven inneholder en egen «folkekirkeparagraf», paragraf 16, noe som gjør at kirken, selv om det ikke lenger er snakk om en statskirke på samme måte som tidligere, fortsatt har en nærmere tilknytning til den norske stat enn andre tros- og livssynssamfunn. Slik sett finnes det fortsatt religiøse bindinger på storsamfunnsnivå i Norge. I barnehagesammenheng gås det i henhold til min tolkning av formålsbestemmelsen og den nye rammeplanen et steg videre enn i grunnloven. Dette skjer ved at skillet mellom kristendommen som religion på storsamfunnsnivå nedtones i den nye rammeplanen. Dette er dermed med på å tydeliggjøre bruddet i formålsbestemmelsen som kom ved innføringen av denne i august 2010.

Når kristendommen nevnes i formålsbestemmelsen og den nye rammeplanen, kommer det i samme åndedrag en henvisning til det religiøse mangfoldet i en eller annen form. Slik nedtones formidling av den kristne kulturarven - den må nødvendigvis få mindre plass når mange andre religiøse tradisjoner også skal formidles. Religion i den nye rammeplanen fremstår dermed ikke lenger som noe som inngår i den verdimessige overbygningen for storsamfunnet. Her er endringen fra tidligere rammeplaner tydelig.

\section{LITTERATUR}

Barnehageloven: Lov 17. juni 2005 nr. 64 om barnehagen. http://www.lovdata.no/all/ nl-20050617-064.html (lastet ned 26.4.2017).

Bellah, Robert. 1986. "Habits of the Heart. Implications for Religion" i http://www. robertbellah.com/lectures_5.htm_(lastet ned 6.2.2016).

Bellah, Robert m.fl. 1996. Habits of the Heart. Individualism and Commitment in American Life. Berkeley: University of California Press.

Berger, Peter L. [1967] 1997. Religion, samfund og virkelighed. Oslo: Vidarforlaget.

Besl. O. nr. 43 (2008-2009) i http://www.stortinget.no/Global/pdf/Beslutninger/ Odelstinget/2008-2009/beso-200809-042.pdf (lastet ned 26.4.2017).

Botvar, Pål Ketil og Schmidt, Ulla (red.). 2010. Religion i dagens Norge. Mellom sekularisering og sakralisering. Oslo: Universitetsforlaget.

Dørum, Knut og Sødal, Helje Kringlebotn (red.). 2016. Mellom gammelt og nytt. Kristendom i Norge på 180o- og 19oo-tallet. Bergen: Fagbokforlaget.

Eriksen, Thomas Hylland og Arntsen Sørheim, Torunn. 2006. Kulturforskjeller i praksis. Perspektiver på det flerkulturelle Norge. Oslo: Gyldendal Akademisk.

Furseth, Inger og Repstad, Pål. 2003. Innføring $i$ religionssosiologi. Oslo: Universitetsforlaget. 
Gadamer, Hans-Georg. 1993. Wahrheit und Methode. Grundzüge einer philosophischen Hermeneutik. 6. Auflage. Gesammelte Werke 1. Hermeneutik I. Tübingen: J.C.B Mohr (Paul Siebeck).

Glaser, Vibeke, m.fl. (red.). 2011. Barnehagens grunnsteiner. Formålet med barnehagen. Oslo: Universitetsforlaget.

Grunnloven: Kongeriget Norges Grundlov, given i Rigsforsamlingen paa Eidsvold den 17de Mai 1814 i https://lovdata.no/dokument/NL/lov/1814-05-17 (lastet ned 26.4 2017)

Hagesæther, Gunhild. 2011. «Barnehagens formål i et historisk perspektiv» i Glaser, Vibeke m.fl. (red.) Barnehagens grunnsteiner. Formålet med barnehagen. Oslo: Universitetsforlaget, 25-36.

Hovdelien, Olav. 2011. Den multikulturelle skolen - hva mener rektorene? Grunnskolerektorer, skolens verdiforankring og religions- og livssynsundervisningen. Kristiansand: Doktoravhandlinger ved Universitetet i Agder 31.

Hovdelien, Olav. 2012. «Barnehagens formålsparagraf - hvordan skal den forstås?» i Prismet. Pedagogisk tidsskrift 2-3:105-113

Hovdelien, Olav. 2013. «A values base for the Norwegian kindergarten. Common ground across cultural affiliations? » i Journal of Moral Education, 42:1, 102-113

Hovdelien, Olav. 2015. «Education and common values in a multicultural society The Norwegian case» i Journal of Intercultural Studies, 36:3, 306-319

Innst. O. nr. 18 (2008-2009) Innstilling fra familie- og kulturkomiteen om lov om endringer i barnehageloven i http://www.stortinget.no/Global/pdf/Innstillinger/ Odelstinget/2008-2009/inno-200809-018.pdf (9.7.2017)

Kunnskapsdepartementet. 2017. Forskrift om rammeplan for barnehagens innhold og oppgaver i https://www.regjeringen.no/contentassets/062a50467a86492b9ab 1829df2433fae/ny-rammeplan-for-barnehagens-innhold.pdf (finnes også i trykt utgave utgitt i april 2017 av Pedlex).

NOU 2007: 6 Formål for framtida. Formål for barnehagen og opplæringen (Bostadutvalget) i http://www.regjeringen.no/pages/1984848/PDFS/ NOU200720070006000DDDPDFS.pdf.

Ot.prp. nr. 47 (2007-2008) Om lov om endringer i barnehageloven (Om formålet med barnehagen).

Parekh, Bhikhu. 2006. Rethinking Multiculturalism. Cultural diversity and political theory. Second Edition. New York: Palgrave Macmillan.

Repstad, Pål. 1984. Mellom himmel og jord. En innføring i religionssosiologi. En fakkelbok.

2. utg. Oslo: Pax forlag.

Repstad, Pål. 2000. Religiøst liv i det moderne Norge. Et sosiologisk kart. 2. utgave. Kristiansand: Høyskoleforlaget.

Repstad, Pål. 2016. «Hvordan fastslå kristendommens virkninger» i Dørum, Knut og Sødal, Helje Kringlebotn (red.) Mellom gammelt og nytt. Kristendom i Norge på 180o- 
og 190o-tallet. Bergen: Fagbokforlaget, 255-269.

Sagberg, Sturla. 2011. «Grunnleggende verdier i kristen og humanistisk arv og tradisjon - hvor grunnleggende er de?» i Glaser, Vibeke m.fl. (red.) Barnehagens grunnsteiner. Formålet med barnehagen. Oslo: Universitetsforlaget, 93-107.

Sagberg, Sturla. 2012. Religion, verdier og danning. Bergen: Fagbokforlaget.

SSB (Statistisk sentralbyrå). 2017a. «Den norske kirke» i https://www.ssb.no/kultur-og-fritid/statistikker/kirke_kostra (lastet ned 19.9.2017).

SSB (Statistisk sentralbyrå). 2017b. «Nøkkeltall for innvandring og innvandrere» i https://www.ssb.no/innvandring-og-innvandrere/nokkeltall/innvandring-oginnvandrere (lastet ned 19.9.2017).

Sødal, Helje Kringlebotn. 2009. Kristen tro og tradisjon i barnehagen. 4. utgave. Kristiansand: Høyskoleforlaget.

Sødal, Helje Kringlebotn. 2014. Kristen tro og tradisjon i barnehagen. 5. utgave. Oslo: Cappelen Damm Akademisk.

$\emptyset$ sterberg, Dag. 2003. Sosiologiens nøkkelbegreper. 6. utgave. Oslo: Cappelen Akademisk Forlag.

Østerberg, Dag og Engelstad, Fredrik. 1995. Samfunnsformasjonen. En innføring i sosiologi. Oslo: Pax forlag.

Aadnanes, Per Magne. 2012. Livssyn. 4. utgave. Oslo: Universitetsforlaget. 